\title{
SIKAP MAHASISWATERHADAP PERKULIAHAN DALAM MENDUKUNG KOMPETENSI PROFESIONAL (STUDI PADA MAHASISWA PROGRAM S 1 KEPENDIDIKAN GURU DALAM JABATAN PROGRAM STUDI PENDIDIKAN BAHASA INGGRIS TAHUN AKADEMIK 2011/2012)
}

\section{Eni Rosnija ${ }^{1}$ \\ Pendidikan Bahasa Inggris FKIPUNTAN erosnija@yahoo.com}

\begin{abstract}
Abtrak :Penelitian ini ini bertujuan untuk mengetahui sikap mahasiswa terhadap perkulihan pada Program Pendidikan Guru Dalam Jabatan dalam mendukung kompetensi profesional.Bentuk penelitian ini adalah penelitan survey. Penelitian ini menggunakan total populasi.Pengumpulan data dilakukan melalui kuisoner. Hasil penelitian menunjukan bahhwa mahasiswa mempunyai sikap yang positif terhadap perkulihan pada Program Pendidikan Guru Dalam Jabatan dalam mendukung kompetensi profesional.
\end{abstract}

Kata Kunci : Sikap dan perkuliahan

\section{Latar Belakang}

Program Sarjana (S-1) Kependidikan bagi Guru dalam Jabatan adalah suatu program penyelenggaraan pendidikan yang secara khusus diperuntukkan bagi Guru dalam Jabatan yang bertugas pada satuan pendidikan formal. Penyelenggaraan program ini bertujuan untuk mendukung upaya percepatan peningkatan kualifikasi akademikbagi guru dalam jabatan sesuai dengan persyaratan yang tertuang dalam Undang-Undang Republik Indonesia Nomor 14 Tahun 2005.

Selama mengikuti perkuliahan pada program ini mahasiswa dibekali ilmu dan keterampilan dalam bidang pengajaran Bahasa Inggris khususnya Teaching English for Young Learner. Beberapa bidang ilmu yang dipelajari selama perkuliahan berlangsung seperti pengajaran,pengembangan materi,

${ }^{I}$ Eni Rosnija adalah dosen Program Studi Pendidikan Bahasa Inggris FKIP Untan 
media pembelajaran, linguistik dan penelitian tentang pengajaran bahasa Inggris yang diarahkan pada penelitian tindakan kelas.

Semua materi perkuliahan dikemas untuk mendukung praktek pengajaran guru di kelas. Oleh karena itu keikutsertaan guru-guru dalam program ini diharapkan dapat mendukung pengembangan kompetensi profesionalisme. Kompetensi profesional yang dimaksud adalah kemampuan pendidik dalam penguasaan materi pembelajaran secara luas dan mendalam yang memungkinkannya membimbing peserta didik memperoleh kompetensi yang ditetapkan.

Berkaitan dengan perkuliahan pada program ini maka dipandang perlu untuk mengetahui sikap para mahasiswa terhadap perkuliahan yang diikuti dalam mendukung kompetensi professional.

\section{Metodologi}

Bentuk penelitian ini adalah penelitan survey yaitu penelitian yang dilakukan untuk untuk memahami tentang karakteristik dari seluruh kelompok yang hendak diteliti atau populasi dengan meneliti sebagian (subset) dari kelompok populasi tersebut yang selanjutnya disebut dengan sampel. Populasi dalam penelitian ini adalah semua mahasiswa Program S1 Guru dalam Jabatan, program studi Bahasa Inggris tahun akademik 20112012 yang terdiri dari kelas A dan B. Penelitian ini menggunakan total populasi. Pengumpulan data dilakukan melalui kuisoner. Instrumen penelitian menggunakan Skala Likert yaitu skala yang dapat dipergunakan untuk mengukur sikap, pendapat, dan persepsi seseorang atau sekelompok orang mengenai suatu gejala atau fenomena pendidikan. Dalam skala Likert terdapat dua bentuk pernyataan yaitu pernyataan positif yang berfungsi untuk mengukur sikap positif, dan pernyataan negative yang berfungsi untuk mengukur sikap negative objek sikap. Skor pernyataan positif dimulai dari 1 untuk sangat tidak setuju (STS), 2 untuk tidak setuju (TS), , 3 untuk setuju (S), dan 4 untuk sangat setuju (SS). Skor pernyataan negative dimulai dari 1 untuk sangat setuju (SS), 2 untuk setuju (S), untuk tidak setuju (TS), dan 4 untuk sangat tidak setuju (STS).

Penskoran :

\begin{tabular}{|l|l|}
\hline Pernyataan & Skor \\
\hline Sangat Setuju & 4 \\
\hline Setuju & 3 \\
\hline Tidak Setuju & 2 \\
\hline Sangat Tidak Setuju & 1 \\
\hline
\end{tabular}


Tabel Unit Analisis

\begin{tabular}{|c|llr|}
\hline No. & Unit Analisis & & \\
\hline 1. & $\begin{array}{l}\text { Sikap mahasiswa terhadap kurikulum yang mendukung } \\
\text { kompetensi professional }\end{array}$ \\
\hline 2. & $\begin{array}{l}\text { Sikap mahasiswa terhadap bahan ajar yang mendukung } \\
\text { kompetensi professional }\end{array}$ \\
\hline 3. & $\begin{array}{l}\text { Sikap mahasiswa terhadap model perkuliahan yang } \\
\text { mendukung kompetensi professional }\end{array}$ \\
\hline 4. & $\begin{array}{l}\text { Sikap mahasiswa terhadap media pembelajaran yang } \\
\text { mendukung kompetensi professional }\end{array}$ \\
\hline 5. & $\begin{array}{l}\text { Sikap mahasiswa terhadap strategi pembelajaran yang } \\
\text { mendukung kompetensi professional }\end{array}$ \\
\hline
\end{tabular}

\section{Hasil Penelitian}

1. Sikap Mahasiswa Terhadap Kurikulum Perkuliahan.

Berdasarkan hasil angket yang disebar ke mahasiswa semester tiga yang berjumlah 26 yang mengikuti Program Sarjana Kependidikan Guru Dalam Jabatan pada tahun akademik 2011/2012 maka di dapat hasil bahwa ada 3 oarang $(11,53 \%)$ yang menyatakan sangat setuju dengan kurikulum perkuliahan yan sesui dengan kebutuhan pembelajar, yang setuju ada 21 orang $(84,62 \%)$, yang tidak setuju hanya 2 orang $(7,69 \%)$ dan tidak ada satupun yang menjawab sangat tidak setuju. Dari data ini dapat disimpulkan bahwa sebagian besar mahasiswa setuju dengan perkuliahan yang berlangsung selama ini memang sesuai dengan kebutuhan pembelajaran di kelas. Tabel berikut menggambarkan sikap mahasiswa tersebut.

\begin{tabular}{|l|l|l|l|l|l|}
\hline No. & Pernyataan & $\begin{array}{l}\text { Sangat } \\
\text { Setuju }\end{array}$ & Setuju & $\begin{array}{l}\text { Tidak } \\
\text { Setuju }\end{array}$ & $\begin{array}{l}\text { Sangat } \\
\text { Tidak } \\
\text { Setuju }\end{array}$ \\
\hline 1. & $\begin{array}{l}\text { Kurikulum perkuliahan } \\
\text { sesuai dengan kebutuhan } \\
\text { pembelajaran di kelas. }\end{array}$ & 3 & 21 & 2 & \\
\hline & & 11,53 & 84,62 & 7,69 & \\
\hline
\end{tabular}

Jika melihat definisi kurikulum yang tercantum dalam Undangundang No. 20 tahun 2003 tentang Sistem Pendidikan Nasional pasal 1 ayat (19) yang berbunyi: Kurikulum adalah seperangkat rencana dan 
pengaturan mengenai tujuan, isi dan bahan pelajaran serta cara yang digunakan sebagai pedoman penyelenggaraan kegiatan pembelajaran untukmencapai tujuan pendidikan tertentu, maka data diatas menggambarkan bahwa seperangkat rencana dan pengaturan mengenai tujuan,isi dan bahan pelajaran sudah sesuai dengan apa yang mereka butuhkan dalam pembelajaran di kelas. Artinya, sesuai dengan kurikulum yang ada pada program studi Pendidikan Bahasa Inggris sesuia dengan kebutuhan mereka pada saat mengajar di kelas masing-masing. Bahkan data menunjukan ada $11,53 \%$ yang sangat setuju dengan kurikulum yang digunakan pada program ini. Ada 7,69 yang tidak setuju kalau kurikulum tersebut sesusi dengan kebutuhan di kelas, namun jumlah tersebut tidak cukup signifikan.

2. Sikap Mahasiswa Terhadap Bahan Ajar Yang Dipakai Dalam Perkuliahan

Dari data angket didapat ada 5 orang ( 19,23) yang menyatakan sangat setuju bahwa bahan ajar yang dipakai selama perkuliahan mendukung penguasaan materi pembelajaran, ada 17 Orang $(65,38 \%)$ setuju, 3 orang $(11,53 \%)$ tidak setuju dan hanya satu oarng $(3,84 \%)$ yang sangat tidak setuju.

\begin{tabular}{|l|l|l|l|l|l|}
\hline No. & \multicolumn{1}{|c|}{ Pernyataan } & $\begin{array}{l}\text { Sangat } \\
\text { Setuju }\end{array}$ & Setuju & $\begin{array}{c}\text { Tidak } \\
\text { Setuju }\end{array}$ & $\begin{array}{c}\text { Sangat } \\
\text { Tidak } \\
\text { Setuju }\end{array}$ \\
\hline 2. & $\begin{array}{l}\text { Bahan ajar yang } \\
\text { dipakai dalam } \\
\text { perkuliahan } \\
\text { mendukung } \\
\text { penguasaan } \\
\text { materi } \\
\text { pembelajaran }\end{array}$ & 5 & 17 & 3 & 1 \\
\hline & & 19,23 & 65,38 & 11,53 & 3,84 \\
\hline
\end{tabular}

Dapat disimpulkan bahwa lebih dari separuh yakni 65,38 \% setuju jika bahan ajar yang digunakan apapun bentuknya baik cetak maupun elektronik dapat mendukung penguasaan materi pembelajaran.

3. Sikap Mahasiswa Terhadap Model Perkuliahan Dapat Dipraktekan di Kelas 
Dari data angket didapat bahwa ada 4 orang (15,38\%) sangat setuju,18 or $(69,23 \%)$ setuju, 2 orang ( 7,69 \%) tidak setuju dan 2 Orang $(7,69 \%)$ sangat tidak setuju. Hal ini bisa dilihat pada table berikut:

\begin{tabular}{|l|l|l|l|l|l|}
\hline No. & Pernyataan & $\begin{array}{l}\text { Sangat } \\
\text { Setuju }\end{array}$ & Setuju & $\begin{array}{l}\text { Tidak } \\
\text { Setuju }\end{array}$ & $\begin{array}{l}\text { Sangat } \\
\text { Tidak } \\
\text { Setuju }\end{array}$ \\
\hline 3. & $\begin{array}{l}\text { Model perkuliahan dapat } \\
\text { diprak- tikan di kelas }\end{array}$ & 4 & 18 & 2 & 2 \\
\hline & \multicolumn{2}{|l|}{15,38} & 69,23 & 7,69 & 7,69 \\
\hline
\end{tabular}

4. Sikap Mahasiswa Tehadap Media Pembelajaran

Kata media merupakan bentuk jamak dari katamedium. Medium dapat didefinisikan sebagai perantara atau pengantar terjadinya komunikasi dari pengirim menuju penerima (Heinich et.al., 2002; Ibrahim, 1997; Ibrahimet.al., 2001). Media merupakan salah satu komponen komunikasi, yaitu sebagai pembawa pesan dari komunikator menuju komunikan (Criticos, 1996). Berdasarkan definisitersebut, dapat dikatakan bahwa proses pembelajaran merupakan proses komunikasi. Proses pembelajaran mengandung lima komponen komunikasi, guru (komunikator), bahan pembelajaran, media pembelajaran, siswa (komunikan), dan tujuan pembelajaran. Jadi, Media pembelajaran adalah segala sesuatu yang dapat digunakan untukmenyalurkan pesan (bahan pembelajaran), sehingga dapat merangsang perhatian, minat,pikiran, dan perasaan siswa dalam kegiatan belajar untuk mencapai tujuan belajar.

Berdasarkan hasil pengisian angket yang menyatakan media pembelajaran yang dipakai dapat diaplikasikan di kelas, ditemukan 4 orang $(15,38 \%)$ yang sangat setuju, 14 orang ( 53,84 \%) setuju, 6 orang $(23,07 \%)$ tidak setuju dan 2 orang $(7,69 \%)$ sangat tidak setuju.

\begin{tabular}{|l|l|l|l|l|l|}
\hline No. & Pernyataan & $\begin{array}{l}\text { Sangat } \\
\text { Setuju }\end{array}$ & Setuju & $\begin{array}{l}\text { Tidak } \\
\text { Setuju }\end{array}$ & $\begin{array}{l}\text { Sangat } \\
\text { Tidak } \\
\text { Setuju }\end{array}$ \\
\hline 4. & $\begin{array}{l}\text { Media pembelajaran yang } \\
\text { dipakai selama } \\
\text { perkuliahan dapat } \\
\text { diaplikasi kan di kelas }\end{array}$ & 4 & 14 & 6 & 2 \\
\hline & & 15,38 & 53,84 & 23,07 & 7,69 \\
\hline
\end{tabular}


Data ini menggambarkan bahwa dari media yang dipakai selama perkuliahan tidak semua mahasiswa bisa mengaplikasikannya dikelas. Hal in bisa terlihat dari cukup signifikannya persentase yang menyatakan keditaksetujuannya yaitu tidak setuju 23,07 \% dan sangat tidak setuju $7,69 \%$.

5. Sikap Mahasiswa Terhadap Strategi Perkuliahan Yang Dapat Diterapkan di Kelas

Berkaitan denga strategi ini data menunjukan jawaban yang bervariasi yaitu bahwa ada 5 orang $(19,23 \%)$ yang sangat setuju kalau strategi perkuliahan dapat diterapkan dalam proses belajar mengajar di kelas. Sedangkan yang setuju 18 orang $(69,23 \%)$, yang tidak setuju 2 orang $(7,69 \%)$ dan 1 orang $(3,84 \%)$ yang sangat tidak setuju.

\begin{tabular}{|l|l|l|l|l|l|}
\hline No. & Pernyataan & $\begin{array}{l}\text { Sangat } \\
\text { Setuju }\end{array}$ & Setuju & $\begin{array}{l}\text { Tidak } \\
\text { Setuju }\end{array}$ & $\begin{array}{l}\text { Sangat } \\
\text { Tidak } \\
\text { Setuju }\end{array}$ \\
\hline 5. & $\begin{array}{l}\text { Strategi perkuliahan } \\
\text { dapat diterapkan } \\
\text { dalam proses belajar } \\
\text { mengajar di kelas }\end{array}$ & 5 & 18 & 2 & 1 \\
\hline & & 19,23 & 69,23 & 7,69 & 3,84 \\
\hline
\end{tabular}

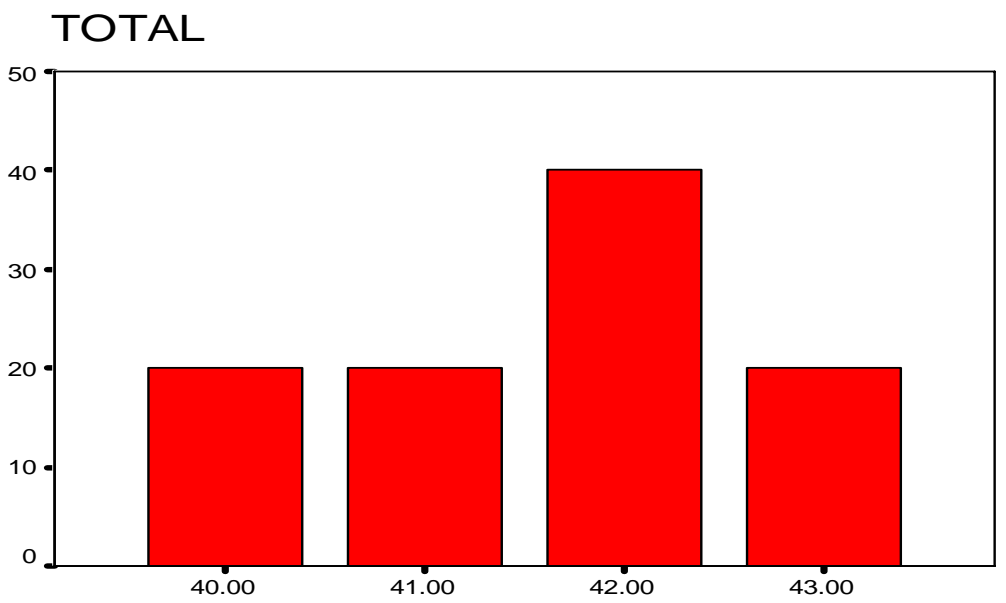

TOTAL 


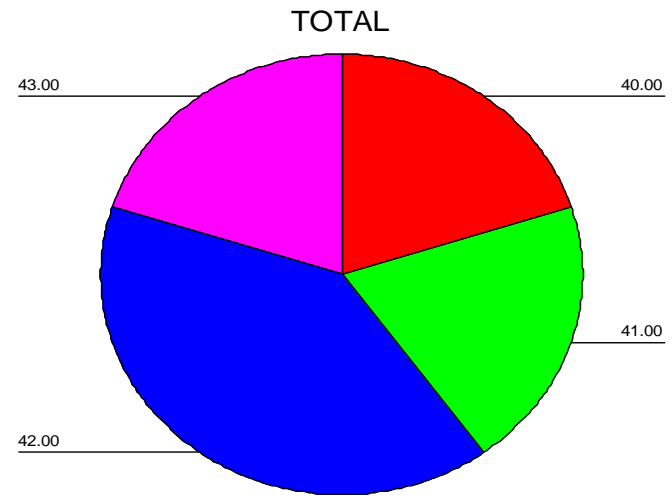

\section{Kesimpulan dan Saran \\ Kesimpulan}

Dari hasil pengisian angket oleh mahasiswa Program Sarjana Kependidikan Guru Dalam Jabatan pada Program Studi Pendidikan Bahasa Inggris pada tahun akademik 2011/2012 maka dapat ditarik beberapa kesimpulan sebagai berikut:

1. Dari segi kurikulum perkuliahan, hampir sebagian besar mahasiswa setuju bahwa kurikulum perkuliahan sudah sesuai dengan pembelajaran di kelas.

2. Untuk bahan ajar lebih dari separuh jumlah mahasiswa menyatakan setuju jika bahan ajar yang dipakai dalam perkuliahan mendukung penguasaan materi pembelajaran.

3. Lebih dari separuh mahasiswa menyatakan setuju bahwa model perkuliahan yang mereka ikuti dapat dipraktikan di kelas.

4. Mengenai media pembelajaran, hanya separuh yang menyatakan setuju jika media yang dipakai selama perkuliahan dapat diaplikasikan di kelas.

5. Berkaitan dengan strategi perkuliahan, lebih dari separuh mahasiswa setuju bahwa strategi perkuliahan dapat diterapkan dalam proses belajar mengajar di kelas.

6. Jika disimpulkan dari semua jawaban yang ada, maka dapat disimpulkan bahwa mahasiswa mempunyai sikap yang positif terhadap perkulihan pada Program Pendidikan Guru Dalam Jabatan dalam mendukung kompetensi profesional.

\section{Saran}


1. Kurikulum perkuliahan sudah sesuai dengan kebutuhan di kelas jadi perlu diteruskan.

2. Bahan ajar dam metode pembelajaan di kelas dapat mendukung peningkatan kompetensi profesional guru sehingga patut untuk dipertahankan.

3. Penggunaan media pembelajaran sebaiknya disesuiakan dengan kondisi masing-masing sekolah.

\section{Daftar Pustaka}

Beaty, Janice J. (1994). Skill for Preeschool Teachers. New Jersey : Merril, an Imprint of

Prentice Hall

Cresswell, John W. (2008). Educational Research.New Jersey: Pearson.

Departemen Pendidikan Nasional. (2005). Peraturan Pemerintah Republik

Indonesia Nomor 19 Tahun 2005 Tentang Standar Nasional Pendidikan.

Jakarta : Departemen Pendidikan Nasional

Dornyei, Zoltan. (2003). Quetionaires in Second Language Research.London, Lawrence Erlbaum Association.

Gunarsa (2003).Psikologi Perkembangan Anak dan Remaja. Jakarta : PT BPK GunungMulya.

Hamalik, Oemar. (2004). Pendidikan Guru Berdasarkan Pendekatan Kompetensi. Jakarta : Bumi Aksara.

Lee McKay, Sandra (2006). Researching Second Language Classrooms.London: Lawrence

Erlabaum Associates Publisher.

Pedoman Teknis (Rambu-Rambu )Penyelenggaraan Pogram Sarjana (S1)

Kependidikan bagi Guru dalam Jabatan, http:/ /www.dikti.go.id dan http://www.kemdiknas.go.id/

Suryabrata, Sumadi (1989), Psikologi Pendidikan, Edisi IV. Jakarta: Penerbit

Rajawali. 